
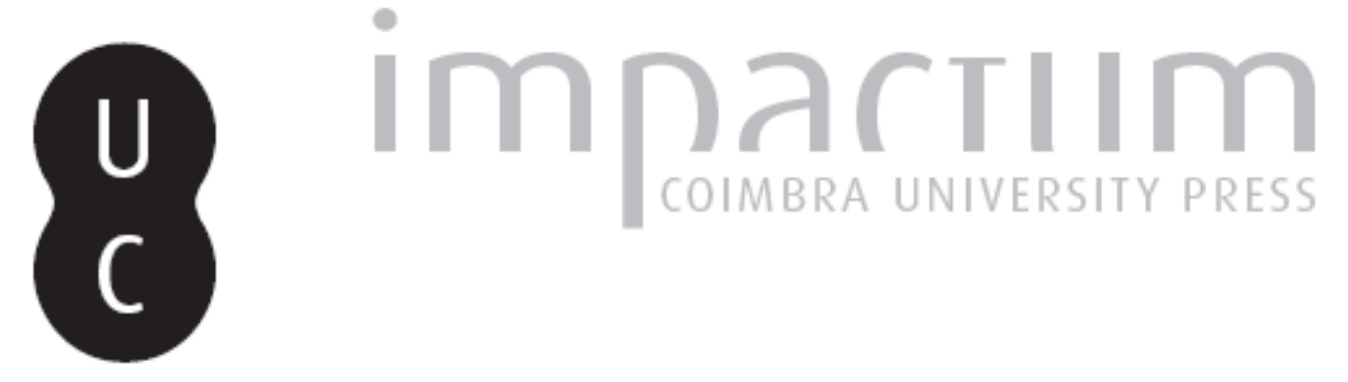

\title{
Plutarch on the question of justice for animals
}

\author{
Autor(es): $\quad$ Steiner, Gary
}

Publicado por: International Plutarch Society

URL persistente:

URI:http://hdl.handle.net/10316.2/36380

DOI:

DOI:http://dx.doi.org/10.14195/0258-655X_7_6

Accessed : $\quad$ 26-Apr-2023 08:13:36

A navegação consulta e descarregamento dos títulos inseridos nas Bibliotecas Digitais UC Digitalis, UC Pombalina e UC Impactum, pressupõem a aceitação plena e sem reservas dos Termos e Condições de Uso destas Bibliotecas Digitais, disponíveis em https://digitalis.uc.pt/pt-pt/termos.

Conforme exposto nos referidos Termos e Condições de Uso, o descarregamento de títulos de acesso restrito requer uma licença válida de autorização devendo o utilizador aceder ao(s) documento(s) a partir de um endereço de IP da instituição detentora da supramencionada licença.

Ao utilizador é apenas permitido o descarregamento para uso pessoal, pelo que o emprego do(s) título(s) descarregado(s) para outro fim, designadamente comercial, carece de autorização do respetivo autor ou editor da obra.

Na medida em que todas as obras da UC Digitalis se encontram protegidas pelo Código do Direito de Autor e Direitos Conexos e demais legislação aplicável, toda a cópia, parcial ou total, deste documento, nos casos em que é legalmente admitida, deverá conter ou fazer-se acompanhar por este aviso.

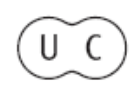




\section{PLOUTARCHOS, n.s.}

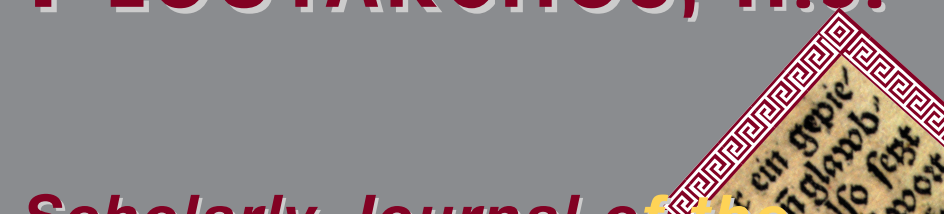

\section{Scholarly Journal o}

International Plut
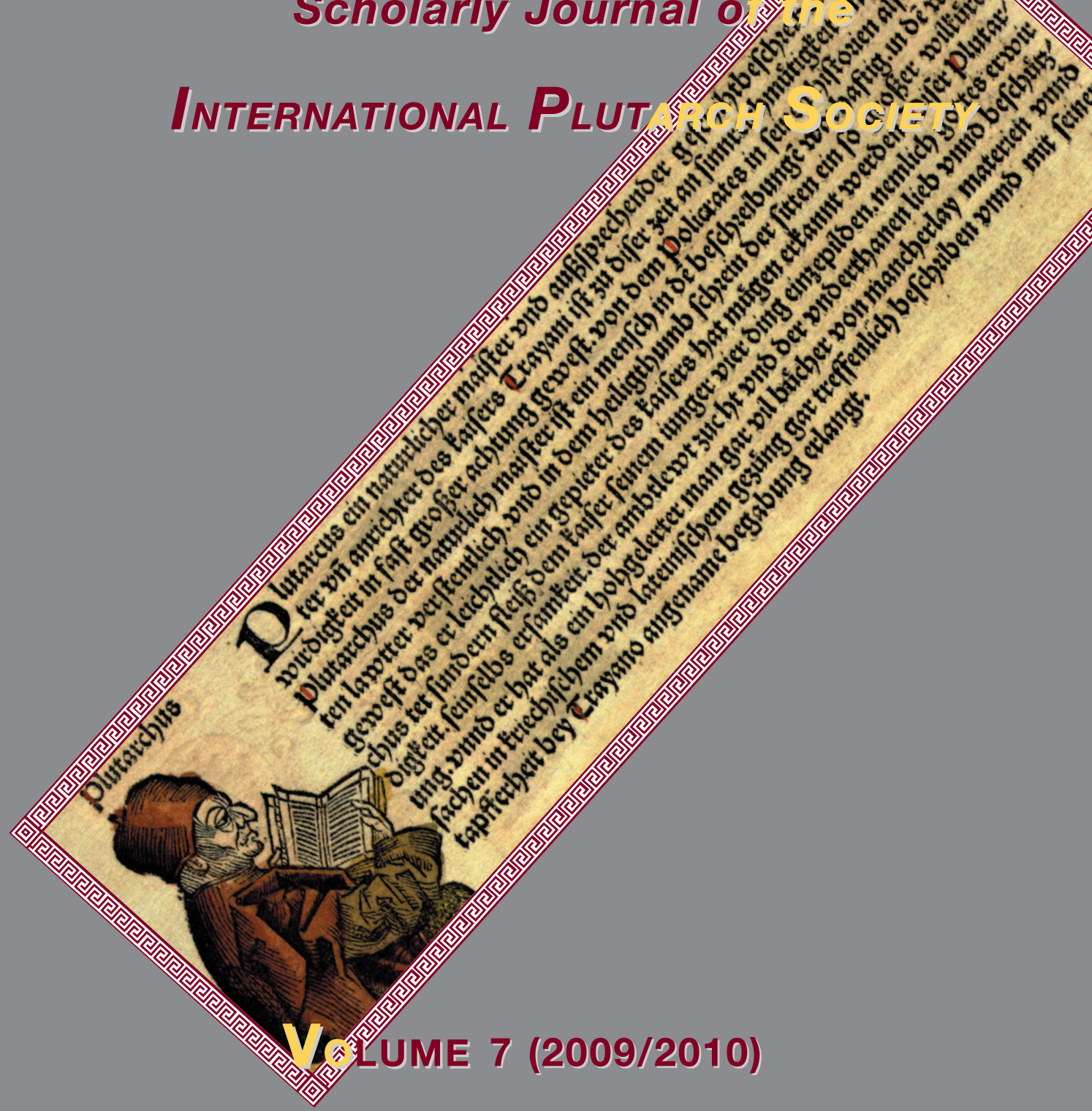

UNIVERSITY OF MÁLAGA (SPAIN) Utah State University, Logan, Utah (U.S.A.) 


\title{
Plutarch on the Question of Justice for Animals by \\ Gary Steiner \\ Bucknell University \\ gsteiner@bucknell.edu
}

\begin{abstract}
Plutarch devotes his three texts on animals in the Moralia to a thoroughgoing critique of the Stoic prejudices of his time. In doing so, he advances two sorts of reason why we should not kill and eat animals: on the grounds that meat-eating and other forms of cruelty to animals interfere with the human pursuit of virtue, and on the grounds that animals merit direct moral concern inasmuch as they possess rationality, language, and emotions. Both of these lines of reasoning motivate Plutarch's advocacy of vegetarianism. Late in life, however, Plutarch retreats from the robust defense of animals that he advanced in the Moralia. A reflection on the shift in Plutarch's thinking about animals helps us to think through a central question in contemporary animal rights debates: exactly what are the appropriate criteria for determining whether a given living being is owed duties of justice? A consideration of the specific experiential abilities that Plutarch attributes to animals in the Moralia, as well as on the Stoics' main reasons for excluding animals from the sphere of right, is an excellent starting point for thinking through this question.
\end{abstract} Key-Words: Plutarch, Moralia, Justice, Animals, Critique of the Stoics.

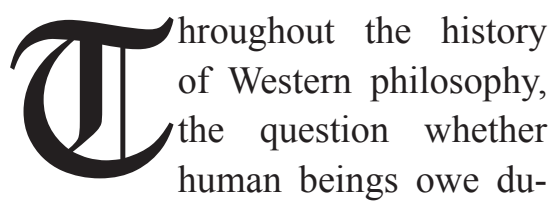

ties of justice to animals has been hotly contested. According to the dominant line of thinking, which extends from Hesiod to John Rawls, only those beings capable of logos are properly members of the sphere of justice. In the Works and Days, Hesiod states that a being must be able to "listen to justice" in order to be its beneficiary ${ }^{1}$. In A Theory of Justice, Rawls asserts in a similar spirit that "the capacity for a sense of justice is necessary in order to be owed the duties of justice." 2

1 Hesiod, Works and Days 213, 275.

2 John Rawls, A Theory of Justice, revised ed. (Cambridge, MA: Belknap/Harvard University Press, 1999), p. 448. 
For Rawls as for Hesiod, the fact that animals lack the rational capacity that is requisite for "listening to" or "having a sense of" justice categorically excludes them from the sphere of right.

In the nearly three thousand years that intervene between Hesiod and Rawls, philosophers have had little to say about the question of justice for animals that is in any way at variance with this conventional wisdom. In this connection, Plutarch proves to be an exception, if ultimately a disappointing one. Thinking about animals in the Western philosophical tradition has long been dominated by the view that human beings are both cognitively and morally superior to animals. Aristotle, even though he acknowledges the cognitive capacities of many animals in his zoological writings, ultimately excludes animals from the sphere of morality and justice in his ethical and psychological writings on the grounds that animals are aloga. The Stoics formalize Aristotle's exclusion into a cosmic principle, arguing that animals were made for the sake of human beings, that animals possess no rational capacity whatsoever, and that animals are categorically excluded from the sphere of right. The Stoics maintain without exception that human and animal experience are fundamentally unlike one another and that nothing we do to animals can possibly be construed as an injustice. Thus when Seneca deplores the delight people take in watching their dinner of surmullet die at the table, he is expressing outrage not at any injustice done to surmullets but rather at human extravagance ${ }^{3}$. Saint Thomas Aquinas and Immanuel Kant later assert a similar view, according to which the only reason to avoid cruelty to animals is that such cruelty makes us more likely to be cruel to human beings.

Implicit if not explicit in all such views about our relations to animals is the conviction that it makes no sense whatsoever to speak of duties of justice toward animals. Justice is conceived as a reciprocal relation between rational agents who are able to see themselves as part of a community of rational individuals. Rational agents can contemplate right rule, subjugate passion to reason, and recognize the ways in which their selfish actions may encroach upon the rightful prerogatives of others. Animals, lacking rationality, are moved immediately by their drives and are incapable of stepping back from the immediacy of desire and evaluating the different goods from which they may choose. In Aristotle's language, animals exhibit volition but are incapable of proairesis or rational choice. According to proponents of this line of thinking, according to which a being cannot be owed duties of justice unless that being can grasp what justice

Seneca, Naturales quaestiones 3.18.3. 
is, any duties we may have toward animals are less demanding than duties of justice; at most, we have duties of mercy or compassion toward animals.

Plutarch is one of a number of philosophers who challenge this line of thinking about the moral status of animals. Plutarch devotes his three texts on animals in the Moralia to a thoroughgoing critique of the Stoic prejudices of his time, developing his critique along two main lines: As a Platonist he deplores meat-eating and other forms of cruelty to animals on the grounds that they interfere with the human pursuit of virtue, that endeavor to emulate the gods that Porphyry would later call "the Olympics of the soul." ${ }^{\text {"But }}$ in those texts Plutarch also expresses an unmistakable direct moral concern for animals; he argues against the Stoics that animals possess rationality, language, and emotions, and he maintains that the cries of animals when we kill them signify a demand for mercy and justice ${ }^{5}$. Thus Plutarch, like Seneca, deplores the practice of watching surmullets die before we eat them for dinner, but for a different reason: For Plutarch, surmullets possess worth in their own right "as being friendly and lifesaving creatures"; hence they merit the "veneration" shown to them by initiates into the Eleusinian mysteries ${ }^{6}$. Plutarch argues that animals "are entitled by birth and being" to the enjoyment and "duration of life," a position that Urs Dierauer characterizes as the "polemical antithesis to Stoic anthropocentrism.",

In countering Stoic anthropocentrism, Plutarch is challenging two interrelated Stoic convictions: that animals exist expressly for the sake of human beings, and that animals lack the capacity for reason and genuine emotion. Even though animals are adiaphora or "indifferents," ultimately the Stoics count them among proegmena or "preferreds" and maintain that they were created to satisfy human needs. Cicero attributes to Chrysippus the view that "with the exception of the world everything else was made for the sake of other things: for example, the crops and fruits which the earth brings forth were made for the sake of animals, and the animals which it brings forth were made for the sake of men...Man himself has come to be in order to contemplate and imitate the world." ${ }^{8}$ Moral conduct, which for the

\footnotetext{
4 See Porphyry, De abstinentia 1.31.3.

5 Plutarch, De esu carnium 994E.

6 Plutarch, De sollertia animalium 983F.

7 Plutarch, De esu carnium 994E; Urs Dierauer, Tier und Mensch im Denken der Antike (Amsterdam: Grüner, 1977), p. 274.

8 Cicero, De natura deorum 2.37-39.
} 
Stoics includes the contemplation of the divine logos, "is the sole thing that is for its own efficacy and value desirable, whereas none of the primary objects of nature is desirable for its own sake." "If animals were rational beings and hence capable of moral conduct, presumably they would possess worth in their own right; but given their lack of rationality, animals are mere instrumentalities for the satisfaction of human physical needs. The satisfaction of these needs is, as Aristotle recognized, a necessary condition for the freedom to devote our time and energy to the task of contemplation. The Stoics offer a variety of arguments in support of the proposition that animals lack rationality. For example, the fact that spiders do not need to learn how to spin webs but instead spin a perfect web on the first attempt shows not that they are acting with any rationality or skill, but rather that they are blind instrumentalities through which nature speaks; and mutatis mutandis for all other animals that act spontaneously through what was until fairly recently dismissed by animal behavior researchers as mere "instinct." 10 The crux of the Stoic dismissal of anything like understanding in animals is their doctrine that the perceptual states of animals lack lekta, that aspect of experience that confers propositional content on perceptual images and makes it possible to grasp and evaluate perceptual objects and emotional states as such. Thus animals are governed not by reason but by orme or impulse ${ }^{11}$. As such, they are incapable of occupying the cosmopolitan standpoint enjoyed exclusively by humans and gods, those beings conceived by the Stoics and much of the subsequent philosophical tradition as being morally superior to non-rational beings.

Plutarch bases his rejection of the Stoic view of animals on the conviction that animals possess precisely those capacities for reason and emotion that the Stoics take as necessary for direct moral status, and that the Stoics categorically deny to animals ${ }^{12}$. Plutarch expresses uncertainty as to whether we should embrace the doctrine of metempsychosis as Pythagoras and Empedocles do in arguing for the injustice of meat eating; but he considers a clear stand on the question of the transmigration of souls not to be necessary for accepting their view that we should "try to accustom [ourselves] to act justly toward other creatures."13 Whether or not Ovid

\footnotetext{
9 Cicero, De finibus 3.21.

10 See Seneca, Ad Lucilium epistulae morales 121.23.

11 See Philo, Allegories of the Laws 2.22-3 (SVF 1.55, 61).

12 Plutarch, De esu carnium 999B.

13 Plutarch, De esu carnium 997E.
} 
is right to characterize the eating of animal flesh as a "Thyestean banquet," we infringe upon something like what Kant would later call inherent worth when we kill and consume animalseven though Kant explicitly denies that animals possess any inherent worth ${ }^{14}$. Plutarch bases his conviction that animals merit justice-land animals, at least, if not sea creatures as wellon "their possession of purpose and preparation and memory and emotions and care for their young and gratitude for benefits and hostility to what has hurt them; to which may be added their ability to find what they need and their manifestations of good qualities, such as courage and sociability and continence and magnanimity." 15 Examples of purpose and preparation include bulls "stirring up dust when intent on battle"; lions walking with their claws retracted so as not "to be dulled by wear at the point or leave a plain trail for trackers"; mother partridges luring predators away from their young; hares hiding their young in scattered places and obscuring their tracks; animals throwing themselves on their masters' funeral pyres; elephants helping their wounded masters as well as each other; dogs demonstrating fidelity by tracking down murderers and thieves, in some instances over a period of days; birds teaching song to their young; a jay that taught itself to mimic funeral trumpets; various animals treating themselves with medications and surgery, as when elephants remove spears from themselves and goats remove arrows; cod evading fishermen's nets; not to mention a cavalcade of skills exhibited by hinds, hedgehogs, she-bears, crocodiles, sea bass, cuttlefish, starfish, sea-hedgehogs, dolphins, and a variety of other land and sea animals ${ }^{16}$. Even if it is implausible to suppose that the cube formation in which tunnies school is a sign that they understand mathematics, Plutarch's point about animal intelligence is clear: animals exhibit forms of subjective awareness that show the Stoic dismissal of intelligence in animals to be unfounded. In attributing technical skill (techne) and understanding (phronein) to a wide variety of animals, Plutarch is asserting something that even Aristotle had documented extensively in his zoological writings and that presentday animal behavior research has amply confirmed: that a wide variety of animals exhibit forms of intelligence which, even if they do not take the form of linguistic or conceptual abstraction exhibited by human beings, nonetheless

\footnotetext{
14 Ovid, Metamorphoses, bk. 15, 1. 462.

15 Plutarch, De sollertia animalium 966B.

16 Plutarch, De sollertia animalium 966C, 971C-D, 970C-D, 969D-E, 972B, 973A-B, 973D, 974B, 974D, 977F.
} 
stand as testimonials to the fact that human beings and non-human animals differ not in kind but at most in degree in their mental capacities.

Plutarch goes so far as to propose that some animals are capable of linguistic communication. In particular, the ability of starlings, crows, and parrots to "learn to talk" demonstrates that "they too are endowed with rational utterance $[\operatorname{logos}$ prophorikos] and with articulate voice [phone]." ${ }^{17}$ This claim about language is a direct repudiation of the Stoic doctrine that animals possess phone but not logos, and that animals are therefore governed by sensation and impulse rather than by reason ${ }^{18}$. Plutarch maintains that "nothing is endowed with sensation [aisthesis] which does not also partake of intelligence [logos] and...there is no living thing which does not naturally possess both opinion [doxa] and reason, just as it has sensation and appetite." 19 Even if we find Plutarch's attribution of linguistic communication to birds implausibleand, given recent ethological research on the communicative abilities of animals such as vervet monkeys, great apes, dolphins, and parrots, we should be cautious about rejecting it too hastily_his claim about the capacity for understanding in many animals has found increasing corroboration in contemporary studies of animal behavior, indeed to such an extent that the Stoic view of animals as blind instinct machines now appears at best alarmingly naïve and at worst transparently self-serving. And even if we must dismiss some of Plutarch's stories about animal intelligence as nothing more than anthropomorphic wish-fulfillments, as when he tells the story of an army of ants that offered another army the ransom of a grub in exchange for the corpse of a dead comrade, his recognition that human beings are not alone in possessing understanding should give us pause when we feel the blind impulse to reaffirm the Stoic prejudice that a being must possess propositional or linguistic capacity in order to count as a beneficiary of justice ${ }^{20}$.

Plutarch's argument that we owe duties of justice to animals is strengthened by his rejection of the Stoic view that animals lack emotion and the capacity for virtue. The Stoics emphasize the connection between rationality and the passions; Chrysippus maintains that passions are judgments about the presence of something beneficial or harmful, so that,

\footnotetext{
17 Plutarch, De sollertia animalium 973A.

18 Diogenes Laertius VII.55, VII.86.

19 De sollertia animalium 960D-E.

20 De sollertia animalium 967E.
} 
having denied logos to animals, he is able to infer the lack of emotional states in animals as well ${ }^{21}$. The Stoics believe that this difference between human beings and animals (namely logos) puts humans in the position of being able to develop control over their drives and hence to be subject to praise and blame, whereas animals, because they do not supplement their impressions with judgments, cannot be subject to praise and blame but instead are simply subject to human beings ${ }^{22}$. In this respect the Stoics anticipate Aquinas's view of animals as non agunt sed magis aguntur: because animals cannot discriminate between and deliberate on the relative merits of different possible objects of desire, those objects function as causes and the responses of animals are merely passive effects ${ }^{23}$. Plutarch attacks this conception of animals quite energetically, offering examples of love in animals, specifically love for human beings, as when an elephant at Alexandria made himselfAristophanes' rival for the affections of a particular flower girl, and a serpent fell in love with an Aetolian woman, took to sleeping with her at night, and became petulant when the woman moved away ${ }^{24}$. Plutarch considers it "extraordinary that [the Stoics] obviously fail to note many things that animals do and many of their movements that show anger or fear or, so help me, envy or jealousy. They themselves punish dogs and horses that make mistakes, not idly but to discipline them; they are creating in them through pain a feeling of sorrow, which we call repentance." 25 And while Plutarch argues that animals may exhibit particular virtues such as courage or repentance, he stops short of attributing the capacity for moral virtue to animals - not because animals are non-rational, but because they are insufficiently rational to pursue moral virtue $^{26}$. Reason in animals is, Plutarch says, like "a clouded eye"; animals are sufficiently rational to provide for their well-being and to participate in community with each other and, in some cases, with human beings, but they fall significantly short of human beings with regard to "the requirements of justice and social life." ${ }^{27}$ Given

21 Galen, On Hippocrates' and Plato's Doctrines 4.3.2-5.

22 See Diogenes Laertius VII.86, where the Stoics are said to treat reason as technites tes hormes, the artisan of impulse; Seneca, Ad lucilium epistulae morales 113.18; and Epictetus, Discourses 2.8.6-7.

23

24

Saint Thomas Aquinas, Quaestiones disputatae de veritate q. 22, art. 4, resp.

24 De sollertia animalium 972D-F.

25 De sollertia animalium 961D.

26 De sollertia animalium 962C-D.

27 De sollertia animalium 963A-B. 
Plutarch's claim that animals deserve justice, this cannot mean that they are to be excluded from the sphere of right altogether; rather, it seems to amount to the recognition that animals are not sufficiently rational to be capable of taking on moral obligations, but that they nonetheless merit inclusion in considerations of justice as what philosophers in our own generation refer to as "moral patients," beings to whom we have moral obligations even though they cannot take on reciprocal obligations toward us. Plutarch's argument that animals possess a rich if ultimately limited rational capacity invites the conclusion that animals are sufficiently like human beings that it would be arbitrary in the extreme to include ourselves in the sphere of justice while excluding animals. This in turn raises the question whether the capacity for full reciprocity is really an essential precondition for membership in the sphere of justice, as contemporary thinkers such as Rawls have claimed and historical figures from Hesiod to Kant have assumed.

As far as it goes, this argument that we have duties of justice toward animals is highly unusual in the history of Western thought, being based as it is on the proposition that differences between humans and animals are matters of degree rather than of kind, and on the related if merely implicit rejection of the traditional assumption that different levels of cognitive ability correspond to different levels of moral worth. But Plutarch is not entirely consistent in his advocacy of justice for animals. It is revealing that some of the stories that Plutarch tells in the attempt to demonstrate reason in animals make reference without scruple to the human use of animals as tools for the satisfaction of human desires. A particularly colorful example is Plutarch's story of a mule that was forced to carry sacks of salt across a river on a regular basis. The mule discovered that it could lighten its load by lowering itself so that the sacks became immersed in the water, thereby dissolving the salt; when the mule's human master became aware of this, he had the bags filled with wool and sponges so that the mule would learn on its next river crossing that "its cunning was unprofitable" and that it must behave in accordance with its master's wishes ${ }^{28}$. Stories of this kind, such as those in which he describes the training of circus elephants or the punishment of dogs and horses in order to "discipline" them, place Plutarch's views about animals in a somewhat different light $^{29}$. For inasmuch as Plutarch expresses no misgivings whatsoever about such uses of animals, the question arises as to exactly what he 
has in mind when he asserts that we have a justice-relation to animals, and the further question arises whether Plutarch's remark about entitlement to life is really to be equated with a commitment to the inherent worth of animals. Only according to a peculiar conception of inherent worth could one justify what appear to be forms of blatant animal exploitation-unless, that is, one considers training a pachyderm to ride a tricycle to be consistent with the principle that nature "produced [animals] for the sake of their beauty and grace." 30

Perhaps it should not be surprising that, later in his life, Plutarch reverses his position regarding the question of justice for animals by arguing that the sphere of law (nomos) or justice (dike) includes only human beings, and that our obligation to animals is merely one of compassion. In his Life of Marcus Cato, Plutarch states that "we know that kindness has a wider scope than justice. Law and justice we naturally apply to men alone, but when it comes to beneficence and charity, these often flow in streams from the gentle heart, like water coming from a copious spring, even down to dumb animals., 31 This reversal on the question of the share that animals have in justice coincides with Plutarch's apparent abandonment of vegetarianism later in life, a change in personal habits that leads the Loeb translators of the treatises on animals to see De esu carnium as nothing more than "a foible of Plutarch's early manhood.",32 This shift in Plutarch's thinking constitutes a weakening of his view concerning our moral obligations toward animals, inasmuch as obligations of mercy or compassion are fundamentally weaker than obligations of justice. Simple confirmation for this is found in the fact that every day we kill animals for our convenience and pleasure, and we do so "with compassion." The passing of every animal welfare measure, such as the recent passage of Proposition 2 in California, stands as a testimonial to our willingness to use animals in a variety of ways, and ultimately to kill them, all "with compassion." Our assertion of duties of compassion has done nothing to reduce the extent of animal exploitation in our society, exploitation so extensive that we now kill 53 billion animals worldwide every year for human consumption. Were we to acknowledge what Plutarch acknowledged earlier in his life, namely, that animals have a right to life and its enjoyment just as we putatively superior humans have, we

De esu carnium 994B.

31 Plutarch, Life of Marcus Cato 5.2.

32 "Introduction" to De esu carnium, Moralia Vol. XII, transl. Harold Cherniss and William Helmbold (Cambridge, MA/London: Harvard University Press, 1995), p. 537. 
could no longer pretend to justify our systematic subjugation of animals as being either necessary or merciful. We would have to see it for what the young Plutarch called it: murder [phonos] with an elaborate rationalization ${ }^{33}$.

33 Plutarch, De esu carnium 994E. 